\title{
Historicity and Status of Higher Education in India
}

\author{
Subal Tandi
}

Department of Humanities and Social Sciences, Central University of Jharkhand, Cheri-Manatu, Ranchi, India

Corresponding author: subaltandi@gmail.com

Received: 18-09-2021 Revised: 27-11-2021 Accepted: 14-12-2021

\begin{abstract}
There are some common factors in the higher education system in India. Higher educational institutions in India are controlled and regulated by the Government. However, many major problems exist in the country such as high population growth, poverty, lack of funding, others economical and political parameters. In view of this, the paper studies the historicity of higher education in India. The paper finds that the present system of higher education of India has been growing rapidly after independence but as less comparative with western as well as neighbouring countries because status of Indians decides on the basis of economic and political parameters rather than education.
\end{abstract}

Keywords: Higher Education, System, Institutions, Historicity, India

Education is general and higher education in particular have passing through many crisis. After independence of India, a number of higher educational institutions emerged in all over the India. The higher education in India has evolved through different periods, viz., ancient, medieval, colonial, post-independence and contemporary era. Higher learning started with an ancient system of education in the Vedic period in which two types of educational system were present there such as the Brahminical and the Buddhist systems of education. The Brahminical system of education was regulated by religious values, while the Buddhist formof education was 'secular' in nature. But the major change in Indian higher education took place through the initiatives of British rulers that made an impact both in positive and negative ways. At that time, the indigenous system of education received a several setback as the British system created a new class which served the British rulers. At present, the number of institutions in India is more than four times the total number of institutions in both the USA and Europe. However, the average size of an Indian higher education institution in terms of enrolment numbers is much smaller (500-600) to that of Europe and the USA $(3,000-4,000)$ and China $(8,000-9,000)$. The knowledge Commission recently advocated the need of expansion of Universities and Colleges in India (Choudhary, 2015).

\section{Historicity of Indian Higher Education}

The education in Ancient India had an outstanding role in creating, transforming and transmitting knowledge to the people in society. Similarly, historical root of higher education system of India involved for social change as well as the human resource development of the country. This system started with the Vedic period. In this period, there were two types of educational system, (i.e. the Brahminical and the Buddhist systems of education. The Brahminical system of education was regulated by religious values while the Buddhist form of education was secular in nature. Rigvedic education was concerned with an attempt to preserve contemporary religious

How to cite this article: Tandi, S. (2021). Historicity and Status of Higher Education in India. Educational Quest: An Int. J. Edu. Appl. Soc. Sci., 12(03): 199-207.

Source of Support: None; Conflict of Interest: None (क) क 
texts through oral transmission. The educational institutions of Rigvedic period (1500 and 1000 B.C) consisted of small domestic schools run by a teacher (Rishi) who admitted pupils for instructions in the literature in its possession. It was also followed by the composition of three more Vedas - Sama, Yajur and Atharva. Women were admitted to full religious rites and educational facilities in this period. The later Vedic period (B.C. 1000-B.C.600) saw continuity as well as some changes in the educational system. The later Vedic period run through the Varna System which was monopolised by the twice born castes in general and by Brahmans inparticular. The teachers were all Brahmins and came from the priestly class. The Post Vedic Early classical Period (600-300B.C.) saw the elaboration of rituals related to education. For instance, the pupil's first introduction to education was made by the performance of a ceremony called Vidyarambha (Choudhary, 2008: 51-52). On the other side, Buddhist education system was religious as well as secular. The teaching of the Buddha classified asVinaya (monolithic discipline), Sutta (group discourse) and Abhidhamma (works of doctrine). Buddhist education was centred inmonasteries and was in the hands of the monks. A Buddhist text includes numerous disciplines or subjects such as the Lokayata system, Astrology,Witchcraft, the four Vedas and Vedangas, Astronomy, interpretation of omens, the philosophical system of Samkhya, Yoga, Nyaya and Vaisheshika, Music, Medicine, Magic, the art of War, poetry, and a number of arts and crafts as well as Arithmetic. Taxila was the most famous Buddhist seat of higher learning. During the reign of Alexander the Great the fame of its philosophers had spread as far as Greece. The student's choice of subjects was not restricted by their caste. Arthasastra was reputed which studied in Taxila. At that time, the universities of Nalanda, Vikramshila and Vallabhi were perhaps the most important universities of ancient India (Ibid., 53-54).

The Mediaeval era in the history of India showed a major phase of social and cultural synthesis. The mediaeval state combined various agencies such as Sufism and Bhakti ideology played a crucial role in the protracted process of integration and coexistence. Madrasah emerged as the important centre of higher education. Mithila was famous for specialised study in Logic during the Mughal period. In mediaeval
India, there were three conduits which were Maktab, Madrasah and Khangah. Maktab was a place where elementary education was imparted, higher learning was pursued at a Madrasah (college) and religious education or theology was discussed at a Khangah, the birth place of Sufism or spiritualism in Islam (p.55-56). The Mughal rulers (1526-1857) showed a comparatively greater interest in higher education. Zahiruddin Muhammad Babar (the founder of the Mughal Empire)was a scholar of Arabic, Persian and Turkish, and established a Madrasah in the locality of Azizullah in Jaunpur. Akbar's reign (1556-1605) opened the doors for Hindu students in pursuance of his policy of education based on religious tolerance and to study Sanskrit and Hindu religious scriptures such as the Upanishads. He also arranged and financed Persian translation of Indian classics and scriptures. Agra acquired a central position in education in the Mughal Empire by the time of Jahangir (1605-1627). Gulbadan Begum (sister of Humayun) wrote the Humayun Nama. It seems that there were learned women for this period (Ibid.,56-57).

Higher education in colonial India, it shows the current university system in India that is influence by the British colonialist. The first Europeanised institution of higher learning in the country began with the establishment of a Hindu College in Calcutta in 1817. In fact, thep resent system of higher education in India has its roots in Mountstuart Elphinstone's minute of 1823 in which he pressed for the establishment of schools for teaching English and the European Sciences. Similarly,Macaulay's minute of 1835 stated the same. The idea of establishing universities in India on the model of the London University (i.e. universities of the affiliating type), was first promoted in Sir Charles Wood's Dispatch of 1854 which has been described as the Magna Carta of English education in India. These recommendations were followed by the establishment of universities at Calcutta, Bombay and Madras in 1857 following the model of the University of London. Curzon's Government was the first to apply a check to free enterprise in education. At that time, higher education in colonial India did not cover rural scheduled caste or scheduled tribe woman (Ibid., 57-59).

Higher education in the post-independence period based on the basis of future innovation and progress. 
The national leadership had an independent opportunity to tackle the problem of higher education. Jawaharlal Nehru was emphasising the new education of the post independence period must be made relevant to the new national goals of independent India. These national goals are: (a) Democracy, (b) Secularism, (c) Elimination of poverty, (d) to create a socialist society, and (5) to create national integration. The University Grants Commission (1956) came into being and assumed a most important role in the co-ordination and development of universities in India. A number of the recommendations of the Radhakrishnan Commission have been implemented including the expansion of women's education at all levels. The Kothari Commission was one of most important for the development of higher education. Thus, there have been various commissions and committees appointed by the Government of India from time to time to development of higher educational institutions (Ibid., 59-61).

\section{Structure of Higher Education in India}

The structure of Indian higher education comprises three years of education after 12 years of schooling $(10+2+3)$, leading to a bachelor's degree in arts and sciences and four years in professional fields like engineering, medicine, management and others. This is followed by two years of study for a Master's degree and thereafter at least three years for a Ph.D degree. Some Universities have provisions for a prePh.D., M.Phil. degree course of two years. Similarly, there are offered some courses like Post-school fiveyear professional course in Law and Post-graduate diploma programmes (Das, 2007:48).

In keeping with, two major types of Universities exist in India- (a) unitary University which offers both graduate and post-graduate courses and (b) affiliating University, which mainly offers postgraduate courses and prescribes to the affiliated colleges the courses of study and hold examinations and award degrees for courses organized both at the University and College levels. The affiliated colleges mostly run either by state governments or private agencies generally impart undergraduate studies, although there is a growing trend of colleges also conducting post-graduate courses. About 65.77 percent of post graduate students are currently attached to affiliated college (UGC, 2006:47).

\section{Growth of Indian Higher Education before and after Independence}

India occupies an important position in respect of Higher Education. Comparing with other countries in the world, India's position in the field of Higher Education system is third after the United States and China. In below the table shows the higher educational trend from pre-independence to post independence.

Table 1: Higher Education in India from preindependence to post independence

\begin{tabular}{lllll}
\hline Year & $\mathbf{1 8 8 3}$ & $\mathbf{1 9 2 8}$ & $\mathbf{1 9 4 7}$ & $\mathbf{1 9 6 1 - 6 2}$ \\
\hline No. of Colleges & 139 & 307 & 591 & 2282 \\
$\begin{array}{l}\text { No. of } \\
\text { Enrolment }\end{array}$ & 16,088 & 90,677 & $2,28,881$ & $11,77,245$ \\
\hline
\end{tabular}

Source: UGC report, January 2011 cited in Majumdar and Sikdar, 2017, pp-11.

In the above table 1, the number of higher educational institutions and number of students have been increasing after independence that means 16, 088 students enrolled in 1883 for higher learning which increased to $11,77,245$ students enrolled in the year 1961-62. Before independence of India, there were 139 colleges in the year 1883 and in 1928, it was 307 colleges. After independence, there is a growth in the educational institutions in India. In 1947, there were 591 colleges. Gradually, it was raised to 40026 colleges in India. However, the educational institutions of the country had been growing fewer tendencies as comparative to population growth in the country.

\section{Growth of Educational Institutions in India}

There are various levels of higher educational institutions in India such as college, university and national importance etc. These institutions are helping the national development as well as bring equality among all deprived sections people of the country.

The table 2 shows the adequacy of growth of higher educational institutions considering population and literature from 1950-51 to 2016-17. From 195051 to 2016-17, there is increase in the both college and universities level institutions. As increase in the population there needs to more educational institution to meet the educated society. As increase in the population and institutions, there is also 
Table 2: Growth of Educational institutions considering population and literacy wise

\begin{tabular}{llllll}
\hline Year & Colleges & Universities & Total Institutions & Population (Millions) & Literacy \\
\hline $1950-51$ & 578 & 27 & 605 & 361 & 21.82 \\
$1955-56$ & 684 & 31 & 715 & 400 & 26.65 \\
$1960-61$ & 1,819 & 45 & 1,864 & 439 & 31.47 \\
$1965-66$ & 2,306 & 64 & 2,370 & 494 & 34.2 \\
$1970-71$ & 3,277 & 82 & 3,359 & 548 & 36.95 \\
$1990-91$ & 5,748 & 184 & 5,932 & 846 & 61.29 \\
$2000-01$ & 10,152 & 254 & 10,406 & 1028 & 69.14 \\
$2005-06$ & 16,982 & 350 & 17,332 & 1119 & 74.2 \\
$2010-11$ & 32,974 & 621 & 33,595 & 1210 & 79.31 \\
$2014-15$ & 38,498 & 760 & 39,258 & 1283 & 83.4 \\
$2016-17$ & 40,026 & 864 & 40,026 & 1299 & 85.2 \\
\hline
\end{tabular}

Source: Data source MHRD report 2015-16 and AISHE 2016-17, Census 2011.

Table 3: Growth of universities from 2011-12 to 2016-17

\begin{tabular}{|c|c|c|c|c|c|c|}
\hline \multirow{2}{*}{ University Type } & \multicolumn{6}{|c|}{ Number of Universities } \\
\hline & 2011-12 & 2012-13 & 2013-14 & 2014-15 & 2015-16 & 2016-17 \\
\hline Institute of National Importance & 59 & 62 & 68 & 75 & 75 & 100 \\
\hline Central University & 42 & 42 & 42 & 43 & 43 & 44 \\
\hline State Public University & 286 & 292 & 309 & 316 & 329 & 345 \\
\hline Deemed University-Government & 38 & 36 & 36 & 32 & 32 & 33 \\
\hline State Private University & 105 & 122 & 153 & 181 & 197 & 233 \\
\hline Deemed University-Private & 79 & 80 & 80 & 97 & 97 & 97 \\
\hline Total & 609 & 634 & 691 & 744 & 773 & 852 \\
\hline
\end{tabular}

Source: AISHE Final Report,2015-16; 2016-17; P.39.

increase in the literacy rate in different proportion. In 1950-5,1 the total number of educational institution was 605 but at the end of 2016-17, it was reached to 40,026 , as to the population increases to 361 million in 1950-51 to 1299 million. Thus, the higher educational institutions spread to grow in the every corner of India, but it is growing slowly as compare to population of the country.

\section{Growth of Universities in India}

It is important that the growth of educational institutions in India could develop in an upward direction. Interestingly, it plays the role of development in human life. The data shows clearly that the growth the universities in India.

The table 3 shows the growth of the universities from 2011-12 to 2016-17, there are various types of universities are there such as - Institute of National Importance, Central University, State Public University, Deemed University-Government, State Private University, Deemed University-Private that 609 number of universities grown in the year 201112 to 852 in 2016-17. It is the symbol of development of the country with human value. Along with as in University so in case of colleges also the number and share of private colleges have increased.

At present out of 40026 colleges in the country. In the total colleges $40 \%$ of the colleges have single programme of which $77.6 \%$ are privately managed, i.e. either they are aided by Government or purely private and unaided colleges so that only $22.4 \%$ of the total number of colleges is running under Government management. Similarly out of the total colleges as high as 40\% (16010 colleges) run 
single programme; B.Ed. and Polytechnic are the important programmes run by these institutions. As high as $77.6 \%$ of such institutions are under private management; Andhra Pradesh, Telengana and Tamil Nadu are the important states in this regard (AISHE, 2016-17).

\section{Gross Enrolment Ratio in Higher Learning in India}

There are 36.6 million enrolments in higher learning with 19.2 million boys and 17.4 million girls; girls constitute 47.6 percent of the total enrolment in 201617.Gross Enrolment Ratio (GER) in higher education in India is 25.8 percent which is calculated for $18-23$ years of age group. GER for male population is 26.3 percent and for females 25.4 percent in the same year. There are 15.9 percent of Scheduled Tribes and 21.8 percent of Scheduled Castes as compared to the national GER of 25.8 percent (AISHE, 2016-17).

\section{Gross Enrolment Rate (GER) With Compare to Others Categories}

Gross Enrolment Rate is a statistical measure for determining the number of students enrolled in undergraduate, postgraduate and research level studies within the country and is expressed as a percentage of the population. Gross Enrolment Ratio (GER) in Higher education in India is $25.2 \%$, which is calculated for 18-23 years of age group. GER for male population is $26.0 \%$ and for females, it is $24.5 \%$. For Scheduled Castes, it is $21.1 \%$ and for Scheduled Tribes, it is $15.4 \%$ as compared to the national GER of $25.2 \%$. The growth of enrolment in higher education can be observed from a modest beginning of 4 lakhs (approx.) in 1950-51 to 357 lakh in 2016-17, i.e. approximately to 90 times during a period of 67 years (MHRD report Higher end Technical Education (HTE) 2007-08, AISHE 2015-16 to 2016-17, p.11).

\section{Pupil Teacher Ratio and Gender Parity Index}

The Pupil Teacher Ratio in higher education was 24 in the year 2015-16 along with the number of teachers were $1,518,813$. The Gender Parity Index (GPI) based on Gross Enrolment Rate (GER) is the ratio of Gross Enrolment Rate of female students enrolled at institutions levels of education to the corresponding ratio of male students at that level.
Table 4: Gender Parity Index in the year 2015-16

\begin{tabular}{lllll}
\hline S1. No. & Particular & All & SC & ST \\
\hline 1 & Higher Education & 0.92 & 0.91 & 0.83 \\
\hline
\end{tabular}

Source: Ibid., p.12.

In the table 4 shows that GPI was 0.92 percent in all categories in 2015-16. GPI of SCs and STs were 0.91 and 0.83 percent in same year. GPI of tribal's students is low as compared to others categories due to sociological reasons such as poverty, regional disparity, low infrastructure facility and so on.

\section{Important Issues in Indian Higher Education}

\section{Expenditure on education}

Public expenditure includes expenditure incurred by the central government, state governments and union territories government and local bodies. In addition to government, Non-governmental agencies, corporate investment and individual household spending also contribute significantly. But the roles of the government still remain pervasive and important.

The table 5 explains that the public expenditure in India comes from the education department and other departments. After independence there is no expenditure from other department, only education department avail the expenditure on education. The education department expenditure was started from 1951-52, where as the other department expenditure was started from 1971-72. From the year 1951-52 to 1991-92 the education department expenditure was increased with $99.65 \%$, from 1992-2002 the expenditure was increase $71 \%$, from 2002-2010 the expenditure was increased with $72 \%$, in the same way from 2002-15 the expenditure was increased with $83.97 \%$. Likewise the other department expenditure also increased over a period of time. From 1971-91 the expenditure on education by other department was increased 99.55\%, from 2001-10 increased with $74.95 \%$, from $2010-15$ increased with $39.01 \%$, and overall from 1971-15 the expenditure was increased with $99.98 \%$. In this analysis it is found that the growth of expenditure was increased by the both education dept. and other dept also.

The total expenditure on education also increased from 1950-51 to 2014-15. From 1951-61 the total 
Table 5: Public Expenditure on Education in India from 1951-52 to 2014-15 (₹ in Crore)

\begin{tabular}{llllll}
\hline \multirow{2}{*}{ Year } & \multicolumn{3}{c}{ Expenditure on education (₹ In Cr.) by } & \multicolumn{2}{c}{ Expenditure on education as \% } \\
\cline { 2 - 6 } & Education Dept & Other Dept. & All department & Total Public Expenditure & GDP \\
\hline $1951-52$ & 64.46 & 0 & 64.46 & 7.92 & 0.64 \\
$1961-65$ & 260.3 & 0 & 260.3 & 11.7 & 1.52 \\
$1971-72$ & 994.82 & 16.25 & $1,011.07$ & 9.53 & 2.25 \\
$1981-82$ & $3,790.15$ & 508.14 & $4,298.29$ & 10.3 & 2.98 \\
$1991-92$ & $18,757.61$ & $3,636.08$ & $22,393.69$ & 13.14 & 3.8 \\
$2001-02$ & $6,4847.7$ & 15,018 & $79,865.7$ & 12.89 & 3.81 \\
$2010-11$ & $23,3510.1$ & $59,968.12$ & $2,93,478.2$ & 14.69 & 4.05 \\
$2011-12$ & $1,90,136.1$ & $1,43,794.3$ & $3,33,930.4$ & 14.84 & 3.82 \\
$2012-13$ & $3,21,754.2$ & $86,667.53$ & $4,08,421.7$ & 15.59 & 3.7 \\
$2013-14$ & $3,65,965.2$ & $99,177.57$ & $4,65,142.8$ & 15.76 & 3.86 \\
$2014-15$ & $40,4591.3$ & $98,338.04$ & $5,02,929.3$ & 12.56 & 4.04 \\
\hline
\end{tabular}

Source: MHRD, Analysis of Budgeted Expenditure on education, 2004 -2015.

Table 6: Public Expenditure on Higher Education in India from 2006 to 2014-15

\begin{tabular}{lllllll}
\hline \multirow{2}{*}{ Year } & \multicolumn{5}{c}{ General University } \\
\cline { 2 - 7 } & Plan & Non-Plan & Total & Plan & Non-Plan & Total \\
\cline { 2 - 7 } In ₹ Cr. & & \multicolumn{3}{c}{ As \% of total exp on education } \\
\hline $2006-07$ & 2170 & 10006 & 12177 & 6.97 & 12.39 & 10.88 \\
$2007-08$ & 4128 & 11449 & 15577 & 10.28 & 12.51 & 11.83 \\
$2008-09$ & 5612 & 12744 & 18356 & 10.95 & 12.35 & 11.89 \\
$2010-11$ & 8385 & 20403 & 28788 & 12.38 & 12.97 & 12.79 \\
$2012-13$ & 11117 & 31387 & 42505 & 10.15 & 14.65 & 13.12 \\
$2013-14$ & 11669 & 35792 & 47461 & 9.29 & 14.89 & 12.97 \\
\hline
\end{tabular}

Source: Adult Basic Education Report (2004-15), https://mhrd.gov.in > adult-education, Access on 12/10/2019).

expenditure increased with $32.30 \%$ from $1951-61$ it was $32.30 \%$ respectively. In the year 1961-71 the total expenditure was decreased by $22.77 \%$. Again in 1971-91 the expenditure increased with $22.47 \%$ and in 1991-2002 it was slidely decreases with $(-1.93 \%)$. from $2002-14$ the expenditure increases with $18.21 \%$ positively, and finally from $2013-15$ the total expenditure decreased with $(-25.47 \%)$.

Hence the expenditure on education increased year by year, the GDP of the country also increases. In 1951-52, the percentage of GDP was 0.64 percent but gradually it was increased up to 4.04 percent. From 1951-02 to 2010-11 the GDP of the country increases but in 2011-12 and 2012-13 the GDP decreases due to decrease of total expenditure.

In particular, another important public expenditure on higher education of India is also consider to analyse.
The table 6 indicates the public expenditure on higher education over time in India from 2006-07 to 2014-15. The expenditure on higher education for the plan expenditure and non plan expenditure was increased from about 11 percent to 13 percent in given year from 2006 to 2014. However, it is not sufficient of budgetary expenditure in the field of higher education.

\section{Accreditation}

In order to improve the skills and talent, there is need for raising the quality and standards of our education system. It is well-known that many of our professionals (engineering/doctors/ management professionals) remain unemployed despite a lot of opportunities being open in the globalized world. One of the major factors is the lack of quality education resulting in qualified but not employable category. However, to encourage 
excellence in higher education the UGC has recently introduced two other schemes to provide autonomy to institutions which have demonstrated high academic standards: The UGC has also established the National Accreditation and Assessment Council (NAAC) to undertake periodic assessment of universities and colleges in the country. While the All India \& Council of Teacher Education has been constituted to plan and coordinate the development of technical education in the country, the National Council for Teacher Education is mandated to maintain the quality of teacher education. Besides, we have other specialized Councils like the Indian Council for Agricultural Research and Indian Council of Medical Research, entrusted to promote teaching and research in respectively agricultural and medical sciences (Das, 2007:48-49).

Despite all these agencies, it is need of the hour to activate the mechanism for rating and ranking universities/colleges. It is, therefore, required a standard rating agencies to give accreditation to universities/colleges/schools more seriously. The various reports on ranking of universities outlined that most of the top ranking universities were from the USA and UK.

\section{Foreign Students Studying in India}

It is interesting for India as well as sign of development of higher education to compete with world level. The Foreign students have been interested to take seat of higher education in India that is show the data in the table 7.

Table 7: Enrolment of Foreign Students in India for Higher Education: 2015-16

\begin{tabular}{lllll}
\hline Sl. No. Country & Male & Female & Total \\
\hline 1 & All Countries & 30,151 & 15,273 & 45,424 \\
2 & Nepal & 6,403 & 3,171 & 9,574 \\
3 & Afganistan & 3,972 & 4,32 & 44,04 \\
4 & Bhutan & 1,677 & 1,248 & 2,925 \\
5 & Nigeria & 1,458 & 632 & 2,090 \\
6 & Sudan & 1,869 & 1,90 & 2,059 \\
7 & Malayasia & 705 & 1,196 & 1,901 \\
8 & United Arab Emirates & 672 & 807 & 1,479 \\
9 & Iran, Islamic Republic & 722 & 737 & 1,459 \\
10 & Yemen & 1164 & 74 & 1,238 \\
11 & Sri Lanka & 511 & 678 & 1,189 \\
12 & Iraq & 981 & 136 & 1,117 \\
13 & All Countries & 30,151 & 15,273 & 45,424 \\
\hline
\end{tabular}

Source: Ibid, p.11.
In the table 7 mentions here that the total numbers of foreign students were 45424 and 9574 number of Nepal's students came into India for higher education that is highest in numbers. The students from Iraq which were 1117 are least numbers as compare to others in the above. Thus, the various reports shows on the foreign students in India are less as compared to the USA and UK.

\section{Making Education Affordable}

In India, if education has to reach all deserving students, it should be made affordable. The fee structure in Government owned/sponsored institutions is inexpensive in India. However, in some private sector institutions, which have the freedom to prescribe fee structure and despite broad guideline from certain state governments, sometimes fees are beyond the capacity of poor and deserving students. Although, the fees charge by some private colleges includes the infrastructural facilities, modern amenities, and so forth, there are still provisions of scholarship schemes, tuitionfee schemes etc. by various govt. regulatory agencies like UGC, AICTE, DDE etc. All such are introduced keeping in mind about the growing need of education and in parlance to the concept of "education for all"

\section{Quality of Education}

The country is showing consistency in economic growth pattern, leading the world in terms of information and technology, modernization, various economic activities and pushing for higher share of industries and services sectors of the economy but there is one area which reform in education system. It is, in fact, clear from the various reports on ranking of higher institutions that not a single institution of higher learning got the position under 200. It is also true that some investments are taking place in the country's higher education system; we are yet to establish world class research facilities, recruiting profound academicians in universities/ colleges/research institutions, etc. to sustain and forge lead in economic development. It is important to understand that countries like China, Singapore, South Korea, etc. are moving fast in investing in education system. Therefore, it is imperative that our educational institutions are equipped with the desired quality and standards which are 
essential for transforming the younger workforce into productive ones. Needless to reiterate that in the higher education system focus on use of technology for effective learning by students also need to be encouraged to have cutting edge over our competitors in the globalized world.

\section{Issue of Equity}

It is commendable that India has developed a very a large network of institutions of higher education. However, mere quantitative growth of institutions alone would not serve the objective of becoming a globally recognised power. There are three main deficiencies, namely, inadequacy in access, uneven and inequitable opportunities of higher education across different categories and sections of the population, and low quality of education imparted in institutions of higher education (Bhoite, 2009:148). The issue of equity in education is intimately related to the prevailing socio-economic in equalities in the society.

\section{Education at Global Level}

The Indian higher education system is the largest in the world in term of the number of institutions as well as foreign students are studying at a large numbers. India has 17, 973 institutions of higher learning as compared to around 2,500 in China. The number of institutions in India is more than four times the number of institutions both in the US and Europe. The Chinese higher education system is the largest in the world in terms of enrolment, which caters to nearly 23 million students followed by the US and India. However, the average size of an Indian higher education institution in terms of enrolment is much smaller (500-600) compared to that of Europe and US (3,000-4,000) and China $(8,000-9,000)$ (Agrawal, 2006:5). It is estimated that even after having the largest number of higher education institutions, India needs at least 3,000 more universities each having the capacity to enrol not less than 10,000 students to meet the increasing demand for higher learning (Bhargava, 2006).

\section{Finding}

Higher education has been the dominant as well as crucial sector in India. It affects and influences all aspect of human development. In fact, Higher education is also symbol of prestige and social status. Higher education is controlled and regulated by the Government of India. The Indian higher educational institutions (more than 85 percent) are in the hand of Government. The country had been the background of religious based higher education from ancient times to contemporary era. Hindu and Budhist ways were the basis of Indian system of higher learning whereas Nalanda, Taxila, and Vikramsila were renowned seats of higher learning. It is attracting students from far and wide including countries such as China, Korea, Burma, Ceylon, Nepal and Tibet. In other sense, Indian system of higher learning was also influenced by other religious thought, especially, Madras and Islamic rule of education which become dominant side by side. Similar way, modern higher education which has been influenced the western system of education as a result of English became the medium of instruction of higher learning. Most of the colleges and universities of India have adopted the western pattern of education.

In fact, there are many divisions as discussed that central universities and institutions are in better conditions because these institutions are funded and budgeted completely by the Central Government as a result there is no crises of expenditure on higher educational institutions. In these ways, private institutions in India are not rated as good, those students who do not get admission in good institution or belong to better off family who can afford the expenses of higher education. In India, private institutions do not acquire status as supposed to be only they are considered as money making industry. On the other hand, State colleges and universities are not up to the mark and instruction are followed in their state language with few exemptions and have been facing severe crisis of funding as are regulated by the State Government. So far ranking and accreditation of institutions is concerned that it has made compulsory and there are various bodies to look into this matter but more than 50 percent institutions are not accredited till date.

\section{CONCLUSION}

On the basis of above discussion, it is found that Indian higher education had dominated by religions as far as the present system of education has indirectly or directly influenced by religion. 
However, finally took the seat of modern education has based on English education. The present system of higher education of India has been growing rapidly after independence but as less comparative with western as well as neighbouring countries because status of Indians decides on the basis of economic and political parameters rather than education. Another important point is that the public expenditure on higher education in India is very low at 0.6 percent of the GDP, compared to 2.7 percent in the USA and 2.6 percent in South Korea. It is another essential that the Indian Government has to give priority to educational sector as it is the largest social sectors and affects all spheres of human life. The Indian Government has to realize and learn how the higher learning institutions are in world ranking under 200 and state higher educational institutions are successful.

\section{REFERENCES}

Adult Basic Education Report, 2004-15. https://mhrd.gov.in > adult-education, Access on 12/10/2019

Agarwal, P. 2006. Higher Education in India: The need for Change, ICRIER Working Paper.

All India Survey of Higher Education, 2017-18. Government of India, Ministry of Human Resource Development, Department of Higher Education, July 2018, pp.1-296, New Delhi-110-115.

Ibid., pp. 11.

Ibid., pp. 12.

Bhargava, A. 2009. Teaching practice for student teachers of B.Ed program: Issues, predicaments \& suggestions. Turkish Online Journal of Distance Education, 10(3).

Bhoite, U.B. 2009. Higher Education in India: A system on the Verge of Chos, Sociological Bulletin, 58(2): 147-177.

Choudhary, S.K. 2008. Higher education in India: a SocioHistorical Journey from Ancient Period to 2006-07, Educational Enquiry, 8(1).
Ibid., pp. 53-54.

Ibid., pp. 56-57.

Ibid., pp. 57-59.

Ibid., pp. 59-61.

Choudhary, S.K. 2015. Education and Society: A Comparative Study of South Korea and India, Presented at RASK International Seminar, University of Delhi, on March, pp. 27-28.

Das, S. 2007. The Higher Education in India and the Challenges of Globalisation, Social Scientist, 35(3/4): 47-67.

Ibid., pp. 48-49.

Government of India, 2004-2015. Analysis of budgeted expenditure on education- 2004-05 to 2006-07, Ministry of Human Resource Development, Department of Higher Education (Planning and Monitoring Unit), New Delhi.

Majumdar, R. and Sikdar, D. 2017. Participation of Tribal Women in Higher Education in India, International Journal of Arts, Humanities and Management Studies, 03(07): 8-16.

MHRD, Higher end Technical Education (HTE) 2007-08, AISHE 2015-16 to 2016-17.

UGC, Report 2006, pp. 47.

UNESCO. 1988. Higher Education in India, UGC Report, New Delhi, UGC.

www.aishe.gov.

www.academics-india.com

www.aicte-india.org

www.aishe.nic.in

www.education.nic.in

www.mhrd.gov.in

www.planningcommission.nic.in

www.ugc.ac.in 
